The Long Gilded Age 
AMERICAN BUSINESS, POLITICS, AND SOCIETY

Series editors

Andrew Wender Cohen, Pamela Walker Laird,

Mark H. Rose, and Elizabeth Tandy Shermer

Books in the series American Business, Politics, and Society explore the relationships over time between governmental institutions and the creation and performance of markets, firms, and industries large and small. The central theme of this series is that politics, law, and public policy—understood broadly to embrace not only lawmaking but also the structuring presence of governmental institutions-has been fundamental to the evolution of American business from the colonial era to the present. The series aims to explore, in particular, developments that have enduring consequences.

A complete list of books in the series is available from the publisher. 


\section{THE LONG GILDED AGE}

AMERICAN CAPITALISM and the LESSONS
of $a$ NEW WORLD ORDER

LEON FINK

$\overline{\text { PENN }}$

UNIVERSITY OF PENNSYLVANIA PRESS

PH I L D E L P I A 
Copyright (C) 2015 University of Pennsylvania Press

All rights reserved.

Except for brief quotations used for purposes of review or scholarly citation, none of this book may be reproduced in any form by any means without written permission from the publisher.

\author{
Published by \\ University of Pennsylvania Press \\ Philadelphia, Pennsylvania 19104-4112 \\ www.upenn.edu/pennpress
}

Printed in the United States of America on acid-free paper

13579108642

Library of Congress Cataloging-in-Publication Data

Fink, Leon, 1948-

The long Gilded Age : American capitalism and the lessons of a new world order / Leon Fink.-1st ed.

p. cm.-(American business, politics, and society)

Includes bibliographical references and index.

ISBN 978-0-8122-4688-9 (hardcover : alk. paper)

1. United States-History-1865-1921. 2. Capitalism-United States-History-19th century. 3. Capitalism-United States-History-20th century. 4. Labor-United States-History-19th century. 5. Labor-United States-History-20th century.

6. Globalization-History-19th century. 7. Globalization-History-20th century. I. Title.

II. Series: American business, politics, and society.

E661.F54 2015

$973.8-\mathrm{dc} 23$

2014029614 
To Nina, Naila, and Julius: A new world is ever being born. 
